\title{
Periarticular Route of Administration
}

National Cancer Institute

\section{Source}

National Cancer Institute. Periarticular Route of Administration. NCI Thesaurus. Code C38292.

Administration of a substance within the tissues surrounding a joint. 